\section{Kidney \\ Blood Pressure Research}

Review

\title{
Cardiovascular Risk and Mineral Bone Disorder in Patients with Chronic Kidney Disease
}

\author{
Hagen Staude Susann Jeske $^{\mathrm{b}} \quad$ Karin Schmitz $^{\mathrm{a}} \quad$ Gert Warncke $^{\mathrm{a}}$ \\ Dagmar-Christiane Fischera
}

aDepartment of Pediatrics, University Children's Hospital Rostock, Germany; ${ }^{b}$ Department of Internal Medicine, University Hospital Rostock, Germany

\section{Key Words}

Calcification - Calcitriol - Cardiovascular risk • Chronic kidney disease-mineral bone disorder $(C K D-M B D) \cdot$ Fetuin-A • Fibroblast growth factor-23 (FGF-23) • Klotho • Parthyroid hormone

\begin{abstract}
The term chronic kidney disease-mineral bone disorder has been coined recently to highlight that the disturbed mineral and bone metabolism is a major contributor to vascular calcification and finally cardiovascular disease. This syndrome is characterized by clinical, biochemical and/or histological findings, i.e. i) biochemical alterations in the homeostasis of calcium, phosphate and their key player parathyroid hormone (PTH), Fibroblast growth factor-23 (FGF23), klotho and vitamin-D, ii) the occurrence of vascular and/or soft tissue calcification, and iii) an abnormal bone structure and/or turnover. Apart from the combined and synergistic action of "traditional" and uremia-related risk factors, promoters and inhibitors of calcification have to be considered as well. This review will focus on the disturbed mineral metabolism as the triggering force behind distortion of vascular integrity and cardiovascular malfunction in CKD patients.
\end{abstract}

Copyright (C) 2013 S. Karger AG, Basel

\section{Introduction}

Chronic kidney disease (CKD) is associated with a severely increased risk of cardiovascular morbidity and mortality [1-6]. Numerous structural and functional alterations of the cardiovascular system, e.g. endothelial dysfunction, arterial stiffening, left ventricular hypertrophy $(\mathrm{LVH})$ and remodeling of the vessel wall with hyperplasia

Dagmar-Christiane Fischer, PhD 


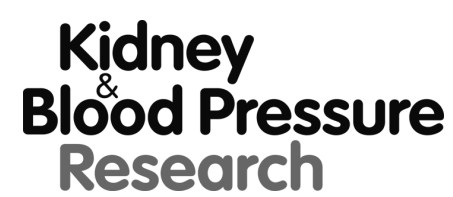

\begin{tabular}{l|l}
\hline \multicolumn{2}{l}{ Kidney Blood Press Res 2013;37:68-83 } \\
\hline \begin{tabular}{l|l} 
DOI: $10.1159 / 000343402$ \\
Publisnea onine. vVrarcn 18, 2013
\end{tabular} & $\begin{array}{l}\text { C } 2013 \text { S. Karger AG, Basel } \\
\text { www.karger.com/kbr }\end{array}$ \\
\hline
\end{tabular}

and calcification occur early in the course of CKD (stage 2-4 CKD) and contribute to the overt risk of ischemic cardiovascular disease (CVD) and sudden cardiac death [6-14]. While an impaired renal function has the potential to aggravate "traditional" risk factors like hypertension, dyslipidaemia, inflammation, and oxidative stress, the concomitant deterioration of mineral homeostasis and thus also bone metabolism is probably the key player leading to accelerated CVD [8]. To highlight the central role of mineral metabolism for both, cardiovascular and skeletal integrity, the term chronic kidney disease-mineral bone disorder (CKD-MBD) was coined recently [15]. This syndrome is characterized by clinical, biochemical and/or histological findings, i.e. i) biochemical alterations in the homeostasis of calcium, phosphate and their key player parathyroid hormone (PTH), Fibroblast growth factor-23 (FGF-23), klotho and vitamin-D, ii) the occurrence of vascular and/or soft tissue calcification, and iii) an abnormal bone structure and/or turnover. Apart from the combined and synergistic action of "traditional" and uremia-related risk factors, promoters and inhibitors of calcification have to be considered as well. This review will focus on the disturbed mineral metabolism in CKD patients as the triggering force behind distortion of vascular integrity and cardiovascular malfunction in these patients.

\section{Vascular calcification}

Calcification can occur either in the tunica intima or tunica media (arteriosclerosis or Mönckeberg's sclerosis) of the vessels. The former is due to intima-media thickening and the formation of atherosclerotic plaques with injury of the intima, local inflammation, dyslipidaemia with subsequent accumulation of foam cells as the main triggering events [16]. Atherosclerosis is restricted to large and medium-sized conduit arteries and has been linked mainly to "traditional" risk factors like smoking, obesity, dyslipidaemia, hypertension and aging. By contrast, media calcification can occur in arteries of any size, is a typical agerelated process and has been associated with increased stiffness and reduced cushioning function $[17,18]$. In patients with diabetes mellitus and/or chronic kidney disease, both forms of calcification are present but are usually not distinguished in epidemiological studies, since non-ambiguous discrimination is hardly achievable unless vessel specimens for histological evaluation are available [19]. Although the initial events leading to either intima or media calcification differ, both reflect an active and highly regulated process closely resembling endochondral and/or intramembraneous bone formation. Furthermore, an inverse association between bone mineralization and vascular mineral burden has been noted in both, the general population and in CKD patients (calcification paradox) $[18,20]$.

\section{Mineral metabolism and chronic kidney disease}

Maintenance of calcium and phosphate homeostasis within rather narrow limits (i.e. $0.8-1.4 \mathrm{mmol} / \mathrm{l}$ for $\mathrm{P}$ and $2.2-2.6 \mathrm{mmol} / \mathrm{l}$ for $\mathrm{Ca}$ ) is of great physiological importance. Phosphate is required for ATP generation, formation of phospholipids and nucleic acids, cellular signaling, and maintenance of $\mathrm{pH}$. Likewise, calcium is critically involved in several physiological processes including neuronal and endothelial signaling, muscle contraction, and blood clotting. Approximately $85 \%$ of total body phosphate and $>98 \%$ of total body calcium are stored in the skeleton, mainly in the form of hydroxyapatite $\left(\mathrm{Ca}_{10}\left(\mathrm{PO}_{4}\right)_{6}(\mathrm{OH})_{2}\right)$ [21-26]. In adults bone remodeling leads to a continuous flow of calcium $(\sim 500 \mathrm{mg} /$ day) and phosphate $(\sim 300 \mathrm{mg} /$ day $)$ out from and into the skeleton $[23,26]$. Numerous epidemiological studies pointed to hyperphosphatemia, hypercalcemia, and an elevated calcium $\mathrm{x}$ phosphate serum product as the main causes of vascular calcification, even in the general population and although the effects of these aberrations are most prominent in patients with end-stage renal disease [27-42] (for a critical review on this topic see also [43]). 


\section{Kidney Blood Pressure Research}

Fig. 1. Average daily turnover of calcium (Ca) and phosphorous $(\mathrm{P})$ in healthy adults $(\mathrm{A})$ and the corresponding regulatory unit of PTH, calcitriol and FGF-23 (B).

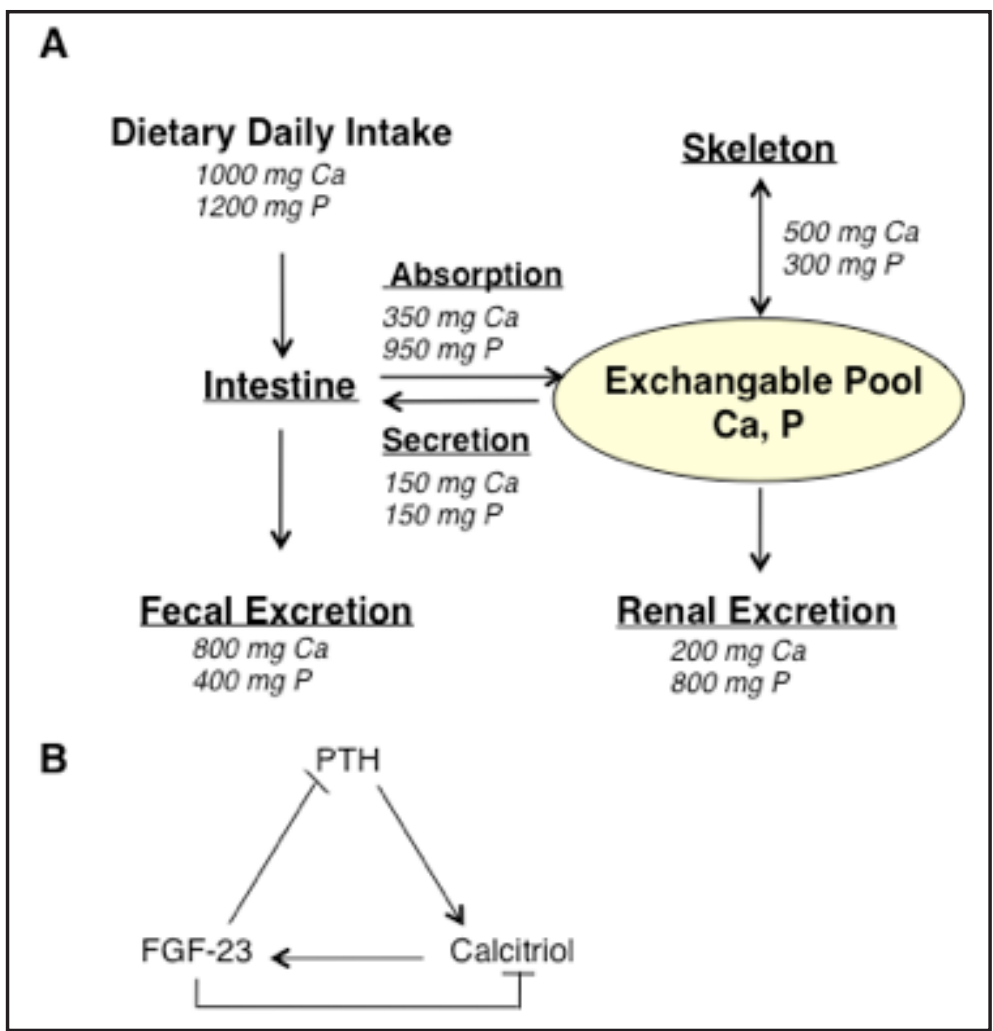

PTH, calcitriol, FGF-23 and klotho form the regulatory system together with their related feeback loops ("bone-parathyroid-kidney axis") for mineral metabolism. Within this circuit the skeleton serves not only as an active mineral repository and endocrine target but also as source of FGF-23 (Figure 1).

A declining GFR is paralleled by a declining renal formation of calcitriol and a subsquently impaired maintenance of calcium homeostasis. A low extracellular calcium level is the main activator of the calcium-sensing receptor (CaSR) in the parathyroid. Activation of the CaSR leads to release of PTH, which exerts its effect via binding to the G-protein coupled PTH receptor (PTHR1) in bone and kidney, i.e. the key regulators of mineral metabolism. In bone, PTH increases the activity of osteoblasts and indirectly of osteoclasts, which in turn stimulates the skeletal release of calcium and phosphate [44]. At the same time, renal phosphate reabsorption is diminished via internalization inhibition of the sodium dependent phosphate cotransporter NaPi-IIa and NaPi-IIc in the proximal tubules while calcium reabsorption is stimulated by activation of calcium channels, e.g. TRPV5 $[25,45,46]$. Likewise, the PTHmediated stimulation of the renal $1 \alpha$-hydroxylase (Cyp27b1) leads to synthesis of 1,25 dihydroxyvitamin $\mathrm{D}_{3}$ (calcitriol). Calcitriol does not only stimulate gastrointestinal calcium and phosphate absorption but also inhibits PTH synthesis [46-48]. In the skeleton, calcitriol transcriptionally activates expression and secretion of FGF-23 in osteoblasts and induces (in cooperation with PTH) the expression of RANK-ligand at the surface of osteoblasts. This finally stimulates osteoclastogenesis and bone turnover. FGF-23, whether induced by calcitriol or hyperphosphatemia, reduces tubular phosphate reabsorption and enhances renal phosphate excretion via inactivation of NaPi-IIa. Furthermore, it inhibits PTH synthesis and renal 1a-hydroxylase (Cyp27b1) while it stimulates the catabolic 24-hydroxylase (Cyp24A1) $[46,49-52]$. Thus, FGF-23 regulates its own expression and closes negative feedback loops between bone, kidney and the parathyroid glands, respectively [46]. However, the complex interaction between FGF-23 and PTH has not been completely understood yet, and whether the increased PTH serum levels in CKD patients are cause or consequence of elevated FGF-23 


\section{Kidney Blood Pressure Research}

\begin{tabular}{l} 
Kidney Blood Press Res 2013;37:68-83 \\
\begin{tabular}{l|l}
\hline DOI: $10.1159 / 000343402$ & (c 2013 S. Karger AG, Basel
\end{tabular} \\
\hline
\end{tabular}

Publisned onime: Tviraren 18, 2013

www.karger.com/kbr

Staude/Jeske/Schmitz/Warncke/Fischer: Cardiovascular Risk in CKD

levels remains to be clarified [46, 49,53-56]. A recent study with healthy volunteers on the effects of a $24 \mathrm{~h}$ infusion of PTH indicated, that FGF-23 secretion is mitigated before calcitriol concentrations increase with subsequent (re-) stimulation of FGF-23 synthesis [57]. In the parathyroid, chronic uremia has been suggested to cause relative resistance to FGF-23 [58, 59].

Under physiological conditions, the endocrine effects of FGF-23 are not only dependent on the presence of FGF-receptors (FGF-R) but also on the protein klotho, which ensures high affinity binding of FGF-23 [49, 51, 60].

Klotho, named after a Greek goddess who spins the thread of life, is a large (120 - 135 $\mathrm{kDa}$ ) type-I membrane protein with a single transmembrane domain near the cytoplasmatic C-terminus which is supposed to anchor the protein to the membrane. It is expressed mainly in the distal convoluted renal tubules, the parathyroid and the epithelium of the choroid plexus in the brain $[49,61,62]$. Proteolytic cleavage releases the extracellular domain into the circulation and this can be detected in blood, urine and cerebrospinal fluid [63-66]. Secreted klotho was shown to act presumably independent from FGF-23 as a humoral factor with pleiotropic activities, e.g. suppression of oxidative stress, inhibition of intracellular insulin- and insulin-like growth factor-1 signaling, regulation of endothelial production of nitric oxide and calcium homeostasis $[56,67,68]$. The latter is of special interest as it puts an additional layer of complexity to the control of mineral metabolism. In particular, phosphate reabsorption occurs in the proximal tubules, while expression of klotho and thus FGF-23 signaling occurs mainly in the distal tubules. It remains to be elucidated whether shedded klotho or an yet unknown mediator signals between distal and proximal tubules [50, 69]. Furthermore, expression and secretion of klotho decreases with age and a recent large population-based study revealed an inverse association with CVD [70].

However, it is still a matter of discussion whether or not klotho-independent effects of FGF-23 exist and our understanding of klotho and FGF-23 signaling is based mainly on data from genetically engineered mice (for review see [71]).

\section{CKD-MBD effects on the cardiovascular system}

A decline of renal function affects mineral metabolism at the excretory (resorption and excretion of $\mathrm{Ca}$ and P) and regulatory level (bone-parathyroid-kidney axis). The endocrine regulation of mineral metabolism as described above brings the interplay of calcitriol, PTH, FGF-23 and klotho into focus, especially in view of the declining kidney function. In fact, calcitriol deficiency together with the secondary hyperparathyroidism (sHPT) and hyperphosphatemia was thought for years to be the main culprit of cardiovascular disease in CKD patients. The identification of FGF-23 as the main regulator of phosphate homeostasis and as a reliable predictor for mortality risk in CKD patients has changed this view considerably within the last decade [72-74]. Thus, cardiovascular remodeling related to CKD is hardly the result of single but complex metabolic aberrations.

In fact, a strong positive association between FGF-23 serum levels, impaired vasoreactivity, atherosclerosis, left ventricular mass index and left ventricular function was seen independently from renal function and mineral status [75-79]. Furthermore, we were able to detect FGF-23 within calcified carotid atheromas derived from patients with preserved renal function, and observed a positive association between the FGF-23 serum concentration and the degree of calcification [80]. Whether this reflects local synthesis as a consequence of osteogenic transformation or accumulation of bone derived FGF-23 remains to be elucidated.

The causative role of FGF-23 was confirmed by in-vivo and in-vitro experiments, and as mentioned above there is evidence for klotho-independent effects of FGF-23. In particular, injection of FGF-23 into rodent models with preserved or impaired renal function $5 / 6$ nephrectomy, 5/6-Nx) caused klotho-independent left ventricular hypertrophy which was attenuated by an FGF-Receptor antagonist [81]. In a more recent study the effects of 


\section{Kidney Blood Pressure Research}

\begin{tabular}{l} 
Kidney Blood Press Res 2013;37:68-83 \\
\hline DOI: 10.1159/000343402 \\
\hline
\end{tabular}

Publisned oninne: Virarcn 18, 2013

www.karger.com/kbr

Staude/Jeske/Schmitz/Warncke/Fischer: Cardiovascular Risk in CKD

antibody-mediated neutralization of FGF-23 was evaluated in a rat model of CKD-MBD. For this purpose, rats underwent 5/6-Nx and were started on normal or high-phosphate diet three weeks before onset of treatment to firmly establish CKD-MBD with sHPT, calcitriol deficiency, hyperphosphatemia and elevated levels of FGF-23. On the one hand, the results met the expectations, i.e. sustained reduction of sHPT, an increase of calcitriol serum levels and an improvement of high-turnover bone disease [82]. On the other hand, neutralization of FGF-23 resulted in a dose-dependent increase of serum phosphate with concomitant aortic calcification and increased risk of mortality. Apart from differences in the experimental settings, these two experiments support, that FGF-23 acts on its own as a pathogenic factor and that increasing FGF-23 concentrations most likely reflect adaptation to CKD [72].

In fact, elevated levels of FGF-23 are already seen in patients with early stages of CKD (GFR $60-90 \mathrm{ml} / \mathrm{min} / 1.73 \mathrm{~m}^{2}$ ), i.e. when serum phosphate is still within the normal range and sHPT is rather mild. In dialysis patients FGF-23 serum concentrations were shown to be clearly associated with vascular calcification and adverse cardiovascular outcome [8390]. Although these findings are in favor of a causative role of FGF-23 in the development and progression of cardiovascular disease, a recent study on the progression of aortic arch calcification during a 5-year interval in non-diabetic patients on chronic hemodialysis $(\mathrm{n}=127)$ revealed an inverse association with the baseline serum concentration of FGF23 [91]. By contrast, a negative association between FGF-23 serum levels and intensity of peripheral calcification was seen in a rather small cohort of diabetic $(n=32)$ and nondiabetic hemodialysis patients $(n=56)$ [85]. These apparently contradictory results may simply reflect the poor standardization of assays used for the determination of FGF-23 serum concentrations [73]. But perhaps even more important, this could indicate that not a single factor but rather a whole and individually mixed cocktail contributes to cardiovascular disease. In this regard, one should keep in mind that PTH and klotho targets cardiovascular cells as well and that klotho deficiency contributes to vascular calcification in-vitro and invivo [73, 92-94].

Hyperphosphatemia as a consequence of reduced renal excretion, SHPT, and an elevated calcium x phosphate serum product have been identified as the culprits of accelerated vascular calcification in CKD patients [95-99]. This notion is strengthened by the recently reported association between hyperphosphatemia and aortic calcification secondary to neutralization of FGF-23 in established CKD-MBD [82]. Several elegant studies with vascular smooth muscle cells (VSMC) have shown that graded concentrations of calcium and phosphate are capable to induce osteogenic/chondrogenic differentiation including matrix vesicle release [100-103]. Likewise, immunohistochemical investigations and in-vivo studies confirmed that vascular calcification closely resembles the mechanisms of endochondral or intramembraneous bone formation, i.e. markers of osteoblasts, chondrocytes and also osteoclasts were readily detectable [80, 104-111]. Apart from high extracellular phosphate and/or calcium concentrations triggering the osteo-/chondrogenic differentiation of VSMCs, degradation of extracellular matrix, the release of apoptotic bodies and apatite containing vesicles contribute to initiation and progression of vascular calcification [26]. In CKD patients therapeutic interventions, e.g. nutrition, prescription of calcium-free and/or calciumcontaining phosphate binders, vitamin D metabolites, calcimimetics, choice of calcium concentration in dialysates, are directed to normalize both, the hormonal regulation and the deteriorated mineral metabolisms. One should keep in mind however, that these measures can add fuel to the fire instead of breaking the vicious circle. Especially, sub- and supraphysiological levels of calcitriol have been associated with poor cardiovascular outcome and increased vascular calcification [112-118]. Although recent animal experiments using calcimimetics in 5/6-Nx rats reduced aortic calcification subsequent to high dose calcitriol and pointed even to a regression of vascular calcification, the available data from a large international placebo-controlled mulitcenter trial are less clear [119-122]. 


\section{Kidney Blood Pressure Research}

\section{Calcification inhibitors}

Osteogenic transdifferentiation of VSMC is now widely accepted as a predominant mechanism of vascular calcification. In addition, the role of mineralization inhibitors (e.g. pyrophosphate (PPi), osteopontin (OPN), osteoprotegerin (OPG), matrix $\gamma$-carboxyglutamic acid protein (matrix gla-protein, MGP) and fetuin-A) has to be considered as well. Especially, VSMC are able to mineralize extracellular matrix via release of matrix vesicles without switching the phenotype when the concentration of mineralization inhibitors are inadequately low or even zero [123-128]. Extracellular PPi interferes with formation of hydroxyapatite nanocrystals and PPi is hydrolysed via a tissue-nonspecific alkaline phosphatase (TNAP). Under conditions of chronic uremia, diminished circulating concentrations of PPi are paralleled by an increase of TNAP acitivity [129-133]. Recent studies with uremic rats indicate that administration of PPi is able to revert this mechanism and to prevent vascular calcification $[134,135]$.

The matrix molecule OPN is a negative regulator of calcification, which is expressed by macrophages, VSMC and endothelial cells. On the one hand it is able to activate osteoclasts via signaling through the $\alpha_{\mathrm{v}} \beta_{3}$ intergrin pathway and on the other hand it may directly bind to apatite crystals thereby interfering with the mineralization process [136-139].

OPG is an important modulator of osteogenesis, i.e. the coordinated differentiation of mesenchymal progenitors and hemopoietic stem cells into osteoblasts and osteoclasts, respectively. This process requires both, the presence of macrophage colony stimulating factor (M-CSF) and binding of RANK (receptor activator of nuclear factor- $\mathrm{kB}$ ), which is expressed at the surface of the pre-osteoclast, to RANKL at the surface of osteoblasts. Binding of OPG to RANKL inhibits this interaction and thus differentiation of osteoclasts. While RANK and RANKL are virtually undetectable in healthy vessel walls, OPG is constitutively expressed in the vessel wall and the circulation, thereby preventing activation of osteoclastogenesis [140, 141]. Whereas overexpression of OPG results in osteopetrosis, diminished concentrations of OPG lead to osteoporosis and vascular calcification in animal models [105, 142, 143]. However, a paradoxical positive association between vascular calcification and OPG serum concentrations has been described in CKD patients [144, 145].

MGP is a potent ubiquitious extracellular inhibitor of vascular calcification in-vivo. It is a small $(10 \mathrm{kDa})$ protein, was initially isolated from bone, and is synthesized predominately by VSMCs and chondrocytes in response to an increase of local calcium levels. The protein exists in an inactive (undecarboxylaed) and an active form, which requires vitamin K-dependent $\gamma$-glutamyl carboxylation. The anti-calcific capacity of MGP drops significantly, when $\gamma$-carboxylation of glutamic acid residues is impaired, i.e. under conditions of oral anticoagulation therapy or vitamin K-deficiency. Animal studies have shown that blocking of vitamin $\mathrm{K}$ lead to rapid and extreme vascular calcification and highlight the functional relevance of this post-translational protein modification [123, 146-149]. In line with this, patients with an inborn lack of mature MGP (Keutel syndrom) suffer from excessive arterial calcification [127]. It has been suggested, that MGP prevents vascular calcification not only via high-affinity binding of calcium, which relies on phosphorylation rather than $\gamma$-carboxylation, but also as an antagonist of bone morphogenetic protein-2 (BMP-2) [101, 150]. In plasma, $\gamma$-carboxylated MGP is carried by fetuin-A and as such part of the fetuiA-mineral complex [151]. Antibodies specific for uncarboxylated and $\gamma$-carboxylated MGP allowed to distinguish between active and inactive forms of this important calcification inhibitor [152]. With this approach an inverse association between vascular calcifcation and the circulating concentrations of uncarboxylated MGP were shown in patients with preserved and reduced kidney function [152-154].

Fetuin-A (also known as $\mathrm{a}_{2}$-Heremans-Schmidt glycoprotein; $\mathrm{a}_{2}$-HS) is constitutively produced in the liver, belongs to the cystatine superfamily of cysteine protease inhibitors, and has long been known as a negative acute phase protein [155-158]. It serves a multitude of biological functions as diverse as antagonizing growth factor mediated signaling, ensuring orthotopic and preventing ectopic mineralization [159-161]. In particular, circulating 


\section{Kidney Blood Pressure Research}

Kidney Blood Press Res 2013;37:68-83

\begin{tabular}{l|l}
\hline DOI: 10.1159/000343402 & (c) 2013 S. Karger AG, Basel
\end{tabular}

Published onine: IVarch 18, 2013

www.karger.com/kbr

fetuin-A acts as a scavenger and cargo for basic calcium phosphates (i.e. acts as calcification inhibitor), preventing formation and precipitation of microcrystals within the circulation $[162,163]$. At the same time, fetuin-A enables mineralization of protein scaffolds, accessible for apatite crystals [164-166]. Although this has been formally proven only in in-vitro studies using demineralized bone or purified bone- and tendon-specific collagen type I, the same mechanisms are likely to operate in vascular calcification, which usually occurs late during the course of the disease. In terms of vascular remodeling, multiple rounds of injury and inflammation may alter structure and properties of the extracellular matrix, i.e. mineral-loaded fetuin-A will adhere to the vessel wall and eventually release its cargo instead of being cleared from the circulation [160]. In such a situation, matrix mineralization is initiated and may progress independently from professional mineralizing cells, although these are required to establish a well organized and highly crystalline mineral phase rather than amorphous precipitation. In a recent study, we clearly showed co-localization of fetuin-A and smooth muscle cell actin (SMA) at sites of tissue remodeling [80]. Both, elevated and reduced serum concentrations of fetuin- $A$, are increasingly recognized as risk markers of cardiovascular and metabolic disease in the general population and in CKD patients, respectively. In particular, elevated serum concentrations of fetuin-A were identified as risk marker for diabetes, metabolic syndrome, myocardial infarction and stroke in the general population [167-169]. In contrast, advanced vascular calcification in adults suffering from end-stage renal disease has been associated with diminished fetuin-A serum concentrations, which in turn were identified as an inflammation-related predictor of cardiovascular and all-cause mortality in dialysis patients $[170,171]$. Likewise, children on dialysis therapy showed significantly reduced fetuin-A serum concentrations as well $[172,173]$. Thus far, several antibody-based assays for the quantitative determination of fetuin-A are available. Although the results are almost always given in absolute units (i.e. g/l), one should keep in mind that apart from poor standardization of the calibrants, the effects of posttranslational fetuin-A modifications like phosphorylation, glycosylation or even binding to other serum compounds including calciumphosphate nanocrystals may interfere with antibody binding $[174,175]$. Especially, increasing calcification stress is paralleled by an increase of mineralloaded fetuin-A, which may escape from quantitative immunological detection [176-179]. High-speed centrifugation of serum was shown in principle to separate free and mineralloaded fetuin-A $[176,180]$. Despite being at first glance a rather simple procedure and direct approach to assess calcification stress more precisely, standardization of the pre-analytical procedures (clotting time, storage of serum samples with respect to time and temperature, centrifugation parameters etc.) are of outmost importance. In addition, a nanoparticlebased test for determination of the overall prospensity for calcification in serum has been reported recently [181].

\section{Conclusion}

Multiple metabolic aberrations in chronic kidney disease contribute to accelerated cardiovascular disease with vascular calcification presenting the hard end of CKD-MBD rather than the beginning. Once firm vascular calcifications are present these are likely to contribute to the progression of disease and to increase the risk of mortality. It might be close to impossible to accuse only one of the factors outlined above as the main culprit, especially in patients with advanced CKD. During the last couple of years vitamin-D has been replaced by FGF-23 as the main denominator of the deranged mineral and bone metabolism in CKD patients. The promotion of FGF-23 from a biomarker of impaired phosphate handling into a pathogenic factor on its own was justified by the ability of FGF-23 to directly induce LVH in rodents [81]. However, targeting FGF-23 serum concentrations in a rat model of CKD improved sHPT and renal osteodystrophy at the expense of increased vascular calcification and mortality [82]. Taken together, the optimal FGF-23 serum level relative to renal function 


\section{Kidney \\ Blood Pressure Research}

remains unknown. Systemic adaptation to a declining renal function is complex, and regardless of the hormonal circuits controlling mineral homeostasis prevention of sustained hyperphosphatemia appears crucial to minimize vascular calcification [72]. Monitoring of mineral metabolism in all of the facets discussed above strongly relies on sensitive and standardized methods.

\section{Conflict of Interests}

None

\section{References}

1 Foley RN, Parfrey PS, Sarnak MJ: Clinical epidemiology of cardiovascular disease in chronic renal disease. Am J Kidney Dis 1998;32:S112-119.

$\longrightarrow 2$ Foley RN: Clinical epidemiology of cardiovascular disease in chronic kidney disease. J Ren Care 2010;36 Suppl 1:4-8.

3 Matsushita K, van der Velde M, Astor BC, Woodward M, Levey AS, de Jong PE, Coresh J, Gansevoort RT: Association of estimated glomerular filtration rate and albuminuria with all-cause and cardiovascular mortality in general population cohorts: A collaborative meta-analysis. Lancet 2010;375:2073-2081.

4 Oh J, Wunsch R, Turzer M, Bahner M, Raggi P, Querfeld U, Mehls O, Schaefer F: Advanced coronary and carotid arteriopathy in young adults with childhood-onset chronic renal failure. Circulation 2002;106:100105.

5 Schiffrin EL, Lipman ML, Mann JF: Chronic kidney disease: Effects on the cardiovascular system. Circulation 2007;116:85-97.

-6 van der Zee S, Baber U, Elmariah S, Winston J, Fuster V: Cardiovascular risk factors in patients with chronic kidney disease. Nat Rev Cardiol 2009;6:580-589.

7 Chavers BM, Li S, Collins AJ, Herzog CA: Cardiovascular disease in pediatric chronic dialysis patients. Kidney Int 2002;62:648-653.

$>8$ Drüeke TB, Massy ZA: Atherosclerosis in ckd: Differences from the general population. Nat Rev Nephrol 2010;6:723-735.

9 Go AS, Chertow GM, Fan D, McCulloch CE, Hsu CY: Chronic kidney disease and the risks of death, cardiovascular events, and hospitalization. N Engl J Med 2004;351:1296-1305.

10 Groothoff JW, Gruppen MP, Offringa M, Hutten J, Lilien MR, Van De Kar NJ, Wolff ED, Davin JC, Heymans HS: Mortality and causes of death of end-stage renal disease in children: A dutch cohort study. Kidney Int 2002;61:621-629.

11 Mitsnefes MM: Cardiovascular complications of pediatric chronic kidney disease. Pediatr Nephrol 2008;23:27-39.

12 Shroff R, Quinlan C, Mitsnefes M: Uraemic vasculopathy in children with chronic kidney disease: Prevention or damage limitation? Pediatr Nephrol 2011;26:853-865.

13 Shroff R, Weaver DJ, Jr., Mitsnefes MM: Cardiovascular complications in children with chronic kidney disease. Nat Rev Nephrol 2011;7:642-649.

14 Lilien MR, Groothoff JW: Cardiovascular disease in children with ckd or esrd. Nat Rev Nephrol 2009;5:229235.

15 Moe S, Drueke T, Cunningham J, Goodman W, Martin K, Olgaard K, Ott S, Sprague S, Lameire N, Eknoyan G: Definition, evaluation, and classification of renal osteodystrophy: A position statement from kidney disease: Improving global outcomes (kdigo). Kidney Int 2006;69:1945-1953.

16 Ross R: Atherosclerosis--an inflammatory disease. N Engl J Med 1999;340:115-126.

17 O'Neill WC, Lomashvili KA: Recent progress in the treatment of vascular calcification. Kidney Int 2010;78:1232-1239.

18 Persy V, D'Haese P: Vascular calcification and bone disease: The calcification paradox. Trends Mol Med 2009;15:405-416. 


\section{Kidney \\ Blood Pressure Research}

Kidney Blood Press Res 2013;37:68-83

DOI: 10.1159/000343402 $\quad$ C 2013 S. Karger AG, Basel

Publisnea onime. ivarari 18, 2013 www.karger.com/kbr

19 Fischer DC, Behets GJ, Hakenberg OW, Voigt M, Vervaet BA, Robijn S, Kundt G, Schareck W, D'Haese PC, Haffner D: Arterial microcalcification in atherosclerotic patients with and without chronic kidney disease: A comparative high-resolution scanning x-ray diffraction analysis. Calcif Tissue Int 2012;90:465-472.

20 Hofbauer LC, Brueck CC, Shanahan CM, Schoppet M, Dobnig H: Vascular calcification and osteoporosis-from clinical observation towards molecular understanding. Osteoporos Int 2007;18:251-259.

21 Parfitt AM: Bone and plasma calcium homeostasis. Bone 1987;8:S1-S8.

22 Parfitt AM: Misconceptions (3): Calcium leaves bone only by resorption and enters only by formation. Bone 2003;33:259-263.

-23 Hruska KA, Mathew S, Lund R, Qiu P, Pratt R: Hyperphosphatemia of chronic kidney disease. Kidney Int 2008;74:148-157.

24 Kovesdy CP, Kalantar-Zadeh K: Bone and mineral disorders in pre-dialysis ckd. Int Urol Nephrol 2008;40:427-440.

25 Kiela PR, Ghishan FK: Recent advances in the renal-skeletal-gut axis that controls phosphate homeostasis. Lab Invest 2009;89:7-14.

26 Shanahan CM, Crouthamel MH, Kapustin A, Giachelli CM: Arterial calcification in chronic kidney disease: Key roles for calcium and phosphate. Circ Res 2011;109:697-711.

27 Kovesdy CP, Kuchmak O, Lu JL, Kalantar-Zadeh K: Outcomes associated with serum calcium level in men with non-dialysis-dependent chronic kidney disease. Clin J Am Soc Nephrol 2010;5:468-476.

28 Larsson TE, Olauson H, Hagstrom E, Ingelsson E, Arnlov J, Lind L, Sundstrom J: Conjoint effects of serum calcium and phosphate on risk of total, cardiovascular, and noncardiovascular mortality in the community. Arterioscler Thromb Vasc Biol 2010;30:333-339.

-29 West SL, Swan VJ, Jamal SA: Effects of calcium on cardiovascular events in patients with kidney disease and in a healthy population. Clin J Am Soc Nephrol 2010;5 Suppl 1:S41-47.

-30 Yamada K, Fujimoto S, Nishiura R, Komatsu H, Tatsumoto M, Sato Y, Hara S, Hisanaga S, Ochiai H, Nakao H, Eto T: Risk factors of the progression of abdominal aortic calcification in patients on chronic haemodialysis. Nephrol Dial Transplant 2007;22:2032-2037.

-31 Block GA: Prevalence and clinical consequences of elevated ca x p product in hemodialysis patients. Clin Nephrol 2000;54:318-324.

-32 Adeney KL, Siscovick DS, Ix JH, Seliger SL, Shlipak MG, Jenny NS, Kestenbaum BR: Association of serum phosphate with vascular and valvular calcification in moderate ckd. J Am Soc Nephrol 2009;20:381-387.

33 Block GA, Hulbert-Shearon TE, Levin NW, Port FK: Association of serum phosphorus and calcium x phosphate product with mortality risk in chronic hemodialysis patients: A national study. Am J Kidney Dis 1998;31:607-617.

-34 Block GA, Klassen PS, Lazarus JM, Ofsthun N, Lowrie EG, Chertow GM: Mineral metabolism, mortality, and morbidity in maintenance hemodialysis. J Am Soc Nephrol 2004;15:2208-2218.

35 Dhingra R, Sullivan LM, Fox CS, Wang TJ, D'Agostino RB, Sr., Gaziano JM, Vasan RS: Relations of serum phosphorus and calcium levels to the incidence of cardiovascular disease in the community. Arch Intern Med 2007;167:879-885.

-36 Kestenbaum B, Sampson JN, Rudser KD, Patterson DJ, Seliger SL, Young B, Sherrard DJ, Andress DL: Serum phosphate levels and mortality risk among people with chronic kidney disease. J Am Soc Nephrol 2005;16:520-528.

-37 Kestenbaum BR, Adeney KL, de Boer IH, Ix JH, Shlipak MG, Siscovick DS: Incidence and progression of coronary calcification in chronic kidney disease: The multi-ethnic study of atherosclerosis. Kidney Int 2009;76:991-998.

38 Noordzij M, Korevaar JC, Bos WJ, Boeschoten EW, Dekker FW, Bossuyt PM, Krediet RT: Mineral metabolism and cardiovascular morbidity and mortality risk: Peritoneal dialysis patients compared with haemodialysis patients. Nephrol Dial Transplant 2006;21:2513-2520.

-39 Tentori F, Blayney MJ, Albert JM, Gillespie BW, Kerr PG, Bommer J, Young EW, Akizawa T, Akiba T, Pisoni RL, Robinson BM, Port FK: Mortality risk for dialysis patients with different levels of serum calcium, phosphorus, and pth: The dialysis outcomes and practice patterns study (dopps). Am J Kidney Dis 2008;52:519-530.

40 Tonelli M, Sacks F, Pfeffer M, Gao Z, Curhan G: Relation between serum phosphate level and cardiovascular event rate in people with coronary disease. Circulation 2005;112:2627-2633. 


\section{Kidney \\ Blood Pressure Research}

Kidney Blood Press Res 2013;37:68-83

DOI: 10.1159/000343402

Publisnea onime. vviarch 18, 2013

C 2013 S. Karger AG, Base

www.karger.com/kbr

-41 Tonelli M, Curhan G, Pfeffer M, Sacks F, Thadhani R, Melamed ML, Wiebe N, Muntner P: Relation between alkaline phosphatase, serum phosphate, and all-cause or cardiovascular mortality. Circulation 2009;120:1784-1792.

$>42$ Young EW, Albert JM, Satayathum S, Goodkin DA, Pisoni RL, Akiba T, Akizawa T, Kurokawa K, Bommer J, Piera L, Port FK: Predictors and consequences of altered mineral metabolism: The dialysis outcomes and practice patterns study. Kidney Int 2005;67:1179-1187.

-43 Palmer SC, Hayen A, Macaskill P, Pellegrini F, Craig JC, Elder GJ, Strippoli GF: Serum levels of phosphorus, parathyroid hormone, and calcium and risks of death and cardiovascular disease in individuals with chronic kidney disease: A systematic review and meta-analysis. JAMA 2011;305:1119-1127.

-44 Lee M, Partridge NC: Parathyroid hormone signaling in bone and kidney. Curr Opin Nephrol Hypertens 2009;18:298-302.

45 Bergwitz C, Jüppner H: Regulation of phosphate homeostasis by pth, vitamin d, and fgf23. Annu Rev Med 2010;61:91-104.

-46 Komaba H, Fukagawa M: Fgf23-parathyroid interaction: Implications in chronic kidney disease. Kidney Int 2010;77:292-298.

-47 Okazaki T, Igarashi T, Kronenberg HM: 5'-flanking region of the parathyroid hormone gene mediates negative regulation by 1,25-(oh)2 vitamin d3. J Biol Chem 1988;263:2203-2208.

-48 Silver J, Naveh-Many T, Mayer H, Schmelzer HJ, Popovtzer MM: Regulation by vitamin d metabolites of parathyroid hormone gene transcription in vivo in the rat. J Clin Inv 1986;78:1296-1301.

49 Razzaque MS: The fgf23-klotho axis: Endocrine regulation of phosphate homeostasis. Nat Rev Endocrinol 2009;5:611-619.

-50 Kuro-o M: Klotho as a regulator of fibroblast growth factor signaling and phosphate/calcium metabolism. Curr Opin Nephrol Hypertens 2006;15:437-441.

51 Kuro-o M: Overview of the fgf23-klotho axis. Pediatr Nephrol 2010;25:583-590.

52 Kuro-o M: Klotho. Pflugers Arch 2010;459:333-343.

-53 Felsenfeld AJ, Rodriguez M, Aguilera-Tejero E: Dynamics of parathyroid hormone secretion in health and secondary hyperparathyroidism. Clin J Am Soc Nephrol 2007;2:1283-1305.

54 Gutierrez 0, Isakova T, Rhee E, Shah A, Holmes J, Collerone G, Juppner H, Wolf M: Fibroblast growth factor-23 mitigates hyperphosphatemia but accentuates calcitriol deficiency in chronic kidney disease. J Am Soc Nephrol 2005;16:2205-2215.

$>55$ Shigematsu T, Kazama JJ, Yamashita T, Fukumoto S, Hosoya T, Gejyo F, Fukagawa M: Possible involvement of circulating fibroblast growth factor 23 in the development of secondary hyperparathyroidism associated with renal insufficiency. Am J Kidney Dis 2004;44:250-256.

56 Drüeke TB: Klotho, fgf23, and fgf receptors in chronic kidney disease: A yin-yang situation? Kidney Int 2010;78:1057-1060.

57 Gutierrez OM, Smith KT, Barchi-Chung A, Patel NM, Isakova T, Wolf M: (1-34) parathyroid hormone infusion acutely lowers fibroblast growth factor 23 concentrations in adult volunteers. Clin J Am Soc Nephrol 2012;7:139-145.

58 Galitzer H, Ben-Dov IZ, Silver J, Naveh-Many T: Parathyroid cell resistance to fibroblast growth factor 23 in secondary hyperparathyroidism of chronic kidney disease. Kidney Int 2010;77:211-218.

59 Komaba H, Goto S, Fujii H, Hamada Y, Kobayashi A, Shibuya K, Tominaga Y, Otsuki N, Nibu K, Nakagawa K, Tsugawa N, Okano T, Kitazawa R, Fukagawa M, Kita T: Depressed expression of klotho and fgf receptor 1 in hyperplastic parathyroid glands from uremic patients. Kidney Int 2010;77:232-238.

60 Urakawa I, Yamazaki Y, Shimada T, Iijima K, Hasegawa H, Okawa K, Fujita T, Fukumoto S, Yamashita T: Klotho converts canonical fgf receptor into a specific receptor for fgf23. Nature 2006;444:770-774.

61 Fukagawa M, Nii-Kono T, Kazama JJ: Role of fibroblast growth factor 23 in health and in chronic kidney disease. Curr Opin Nephrol Hypertens 2005;14:325-329.

62 Razzaque MS: Osteo-renal regulation of systemic phosphate metabolism. IUBMB Life 2011;63:240-247.

63 Bloch L, Sineshchekova O, Reichenbach D, Reiss K, Saftig P, Kuro-o M, Kaether C: Klotho is a substrate for alpha-, beta- and gamma-secretase. FEBS Lett 2009;583:3221-3224.

64 Chen CD, Podvin S, Gillespie E, Leeman SE, Abraham CR: Insulin stimulates the cleavage and release of the extracellular domain of klotho by adam10 and adam17. Proc Natl Acad Sci U S A 2007;104:19796-19801.

65 Chang Q, Hoefs S, van der Kemp AW, Topala CN, Bindels RJ, Hoenderop JG: The beta-glucuronidase klotho hydrolyzes and activates the trpv5 channel. Science 2005;310:490-493. 


\section{Kidney \\ Blood Pressure Research}

Kidney Blood Press Res 2013;37:68-83

\begin{tabular}{l|l}
\hline DOI: $10.1159 / 000343402$ & (c) 2013 S. Karger AG, Basel
\end{tabular}

Publisnea onime: Iviarch 18, 2013

www.karger.com/kbr

66 Imura A, Iwano A, Tohyama O, Tsuji Y, Nozaki K, Hashimoto N, Fujimori T, Nabeshima Y: Secreted klotho protein in sera and csf: Implication for post-translational cleavage in release of klotho protein from cell membrane. FEBS Lett 2004;565:143-147.

67 Kuro-o M: Klotho and the aging process. Korean J Intern Med 2011;26:113-122.

68 Huang CL: Regulation of ion channels by secreted klotho: Mechanisms and implications. Kidney Int 2010;77:855-860.

-69 Liu S, Vierthaler L, Tang W, Zhou J, Quarles LD: Fgfr3 and fgfr4 do not mediate renal effects of fgf23. J Am Soc Nephrol 2008;19:2342-2350.

-70 Semba RD, Cappola AR, Sun K, Bandinelli S, Dalal M, Crasto C, Guralnik JM, Ferrucci L: Plasma klotho and cardiovascular disease in adults. J Am Geriatr Soc 2011;59:1596-1601.

-71 Zoppellaro G, Faggin E, Puato M, Pauletto P, Rattazzi M: Fibroblast growth factor 23 and the bone-vascular axis: Lessons learned from animal studies. Am J Kidney Dis 2012;59:135-144.

72 Ketteler M, Biggar PH, Liangos O: Fgf23 antagonism: The thin line between adaptation and maladaptation in chronic kidney disease. Nephrol Dial Transplant DOI: 10.1093/ndt/gfs557.

73 Wolf M: Forging forward with 10 burning questions on fgf23 in kidney disease. J Am Soc Nephrol 2010;21:1427-1435.

74 Wolf M: Update on fibroblast growth factor 23 in chronic kidney disease. Kidney Int 2012;82:737-747.

75 Mirza MA, Hansen T, Johansson L, Ahlstrom H, Larsson A, Lind L, Larsson TE: Relationship between circulating fgf23 and total body atherosclerosis in the community. Nephrol Dial Transplant 2009;24:31253131.

76 Mirza MA, Larsson A, Melhus H, Lind L, Larsson TE: Serum intact fgf23 associate with left ventricular mass, hypertrophy and geometry in an elderly population. Atherosclerosis 2009;207:546-551.

77 Mirza MA, Larsson A, Lind L, Larsson TE: Circulating fibroblast growth factor-23 is associated with vascular dysfunction in the community. Atherosclerosis 2009;205:385-390.

-78 Kirkpantur A, Balci M, Gurbuz OA, Afsar B, Canbakan B, Akdemir R, Ayli MD: Serum fibroblast growth factor-23 (fgf-23) levels are independently associated with left ventricular mass and myocardial performance index in maintenance haemodialysis patients. Nephrol Dial Transplant 2011;26:1346-1354.

79 Seiler S, Cremers B, Rebling NM, Hornof F, Jeken J, Kersting S, Steimle C, Ege P, Fehrenz M, Rogacev KS, Scheller B, Bohm M, Fliser D, Heine GH: The phosphatonin fibroblast growth factor 23 links calciumphosphate metabolism with left-ventricular dysfunction and atrial fibrillation. Eur Heart J 2011;32:26882696.

-80 Voigt M, Fischer DC, Rimpau M, Schareck W, Haffner D: Fibroblast growth factor (fgf)-23 and fetuin-a in calcified carotid atheroma. Histopathology 2010;56:775-788.

81 Faul C, Amaral AP, Oskouei B, Hu M-C, Sloan A, Isakova T, Gutiérrez OM, Aguillon-Prada R, Lincoln J, Hare JM, Mundel P, Morales A, Scialla J, Fischer M, Soliman EZ, Chen J, Go AS, Rosas SE, Nessel L, Townsend RR, Feldman HI, St John Sutton M, Ojo A, Gadegbeku C, Di Marco GS, Reuter S, Kentrup D, Tiemann K, Brand M, Hill JA, Moe OW, Kuro-o M, Kusek JW, Keane MG, Wolf M: Fgf23 induces left ventricular hypertrophy. J Clin Invest 2011;121:4393-4408.

-82 Shalhoub V, Shatzen EM, Ward SC, Davis J, Stevens J, Bi V, Renshaw L, Hawkins N, Wang W, Chen C, Tsai MM, Cattley RC, Wronski TJ, Xia X, Li X, Henley C, Eschenberg M, Richards WG: Fgf23 neutralization improves chronic kidney disease-associated hyperparathyroidism yet increases mortality. J Clin Inv 2012;122:25432553.

83 Gutiérrez OM, Mannstadt M, Isakova T, Rauh-Hain JA, Tamez H, Shah A, Smith K, Lee H, Thadhani R, Jüppner $\mathrm{H}$, Wolf M: Fibroblast growth factor 23 and mortality among patients undergoing hemodialysis. N Engl J Med 2008;359:584-592.

84 Imanishi Y, Inaba M, Nakatsuka K, Nagasue K, Okuno S, Yoshihara A, Miura M, Miyauchi A, Kobayashi K, Miki T, Shoji T, Ishimura E, Nishizawa Y: Fgf-23 in patients with end-stage renal disease on hemodialysis. Kidney Int 2004;65:1943-1946.

85 Inaba M, Okuno S, Imanishi Y, Yamada S, Shioi A, Yamakawa T, Ishimura E, Nishizawa Y: Role of fibroblast growth factor-23 in peripheral vascular calcification in non-diabetic and diabetic hemodialysis patients. Osteoporos Int 2006;17:1506-1513.

-86 Torres PU, Friedlander G, de Vernejoul MC, Silve C, Prie D: Bone mass does not correlate with the serum fibroblast growth factor 23 in hemodialysis patients. Kidney Int 2008;73:102-107. 


\section{Kidney \\ Blood Pressure Research}

\begin{tabular}{|c|c|}
\hline Kidney Blood Press Res 20 & \\
\hline $\begin{array}{l}\text { DOI: 10.1159/000343402 } \\
\text { Publisnea ontune: vilarcn 18, } 2013\end{array}$ & $\begin{array}{l}\text { (c) } 2013 \text { S. Karger AG, Basel } \\
\text { www.karger.com/kbr }\end{array}$ \\
\hline
\end{tabular}

-87 Zoccali C: Fgf-23 in dialysis patients: Ready for prime time? Nephrol Dial Transplant 2009;24:1078-1081.

88 Larsson T, Nisbeth U, Ljunggren O, Juppner H, Jonsson KB: Circulating concentration of fgf-23 increases as renal function declines in patients with chronic kidney disease, but does not change in response to variation in phosphate intake in healthy volunteers. Kidney Int 2003;64:2272-2279.

-89 Jean G, Bresson E, Terrat JC, Vanel T, Hurot JM, Lorriaux C, Mayor B, Chazot C: Peripheral vascular calcification in long-haemodialysis patients: Associated factors and survival consequences. Nephrol Dial Transplant 2009;24:948-955.

90 Srivaths PR, Goldstein SL, Silverstein DM, Krishnamurthy R, Brewer ED: Elevated fgf 23 and phosphorus are associated with coronary calcification in hemodialysis patients. Pediatr Nephrol 2011;26:945-951.

-91 Tamei N, Ogawa T, Ishida H, Ando Y, Nitta K: Serum fibroblast growth factor-23 levels and progression of aortic arch calcification in non-diabetic patients on chronic hemodialysis. J Atheroscler Thromb 2011;18:217-223.

92 Schlüter KD, Piper HM: Cardiovascular actions of parathyroid hormone and parathyroid hormone-related peptide. Cardiovasc Res 1998;37:34-41.

93 Hu MC, Shi M, Zhang J, Quinones H, Griffith C, Kuro-o M, Moe OW: Klotho deficiency causes vascular calcification in chronic kidney disease. J Am Soc Nephrol 2011;22:124-136.

-94 Lim K, Lu TS, Molostvov G, Lee C, Lam FT, Zehnder D, Hsiao LL: Vascular klotho deficiency potentiates the development of human artery calcification and mediates resistance to fibroblast growth factor 23 . Circulation 2012;125:2243-2255.

-95 Asmus HG, Braun J, Krause R, Brunkhorst R, Holzer H, Schulz W, Neumayer HH, Raggi P, Bommer J: Two year comparison of sevelamer and calcium carbonate effects on cardiovascular calcification and bone density. Nephrol Dial Transplant 2005;20:1653-1661.

-96 Chertow GM, Raggi P, Chasan-Taber S, Bommer J, Holzer H, Burke SK: Determinants of progressive vascular calcification in haemodialysis patients. Nephrol Dial Transplant 2004;19:1489-1496.

\$97 Goodman WG, Goldin J, Kuizon BD, Yoon C, Gales B, Sider D, Wang Y, Chung J, Emerick A, Greaser L, Elashoff RM, Salusky IB: Coronary-artery calcification in young adults with end-stage renal disease who are undergoing dialysis. N Engl J Med 2000;342:1478-1483.

-98 London GM, Guerin AP, Marchais SJ, Metivier F, Pannier B, Adda H: Arterial media calcification in end-stage renal disease: Impact on all-cause and cardiovascular mortality. Nephrol Dial Transplant 2003;18:17311740.

99 Raggi P, Boulay A, Chasan-Taber S, Amin N, Dillon M, Burke SK, Chertow GM: Cardiac calcification in adult hemodialysis patients. A link between end-stage renal disease and cardiovascular disease? J Am Coll Cardiol 2002;39:695-701.

100 Jono S, McKee MD, Murry CE, Shioi A, Nishizawa Y, Mori K, Morii H, Giachelli CM: Phosphate regulation of vascular smooth muscle cell calcification. Circ Res 2000;87:E10-17.

-101 Reynolds JL, Joannides AJ, Skepper JN, McNair R, Schurgers LJ, Proudfoot D, Jahnen-Dechent W, Weissberg PL, Shanahan CM: Human vascular smooth muscle cells undergo vesicle-mediated calcification in response to changes in extracellular calcium and phosphate concentrations: A potential mechanism for accelerated vascular calcification in esrd. J Am Soc Nephrol 2004;15:2857-2867.

102 Proudfoot D, Skepper JN, Hegyi L, Bennett MR, Shanahan CM, Weissberg PL: Apoptosis regulates human vascular calcification in vitro: Evidence for initiation of vascular calcification by apoptotic bodies. Circ Res 2000;87:1055-1062.

103 Shroff RC, McNair R, Figg N, Skepper JN, Schurgers L, Gupta A, Hiorns M, Donald AE, Deanfield J, Rees L, Shanahan CM: Dialysis accelerates medial vascular calcification in part by triggering smooth muscle cell apoptosis. Circulation 2008;118:1748-1757.

104 Neven E, Dauwe S, De Broe ME, D'Haese PC, Persy V: Endochondral bone formation is involved in media calcification in rats and in men. Kidney Int 2007;72:574-581.

105 Dellegrottaglie S, Sanz J, Rajagopalan S: Molecular determinants of vascular calcification: A bench to bedside view. Curr Mol Med 2006;6:515-524.

106 Demer LL, Tintut Y: Vascular calcification: Pathobiology of a multifaceted disease. Circulation 2008;117:2938-2948.

107 Hruska KA, Mathew S, Saab G: Bone morphogenetic proteins in vascular calcification. Circ Res 2005;97:105-114. 


\section{Kidney \\ Blood Pressure Research}

Kidney Blood Press Res 2013;37:68-83

\begin{tabular}{l|l}
\hline DOI: 10.1159/000343402 & (C) 2013 S. Karger AG, Base
\end{tabular}

Publisned onIIne: IVIarch 18, 2013

www.karger.com/kbr

108 Hunt JL, Fairman R, Mitchell ME, Carpenter JP, Golden M, Khalapyan T, Wolfe M, Neschis D, Milner R, Scoll B, Cusack A, Mohler ER, 3rd: Bone formation in carotid plaques: A clinicopathological study. Stroke 2002;33:1214-1219.

109 Johnson RC, Leopold JA, Loscalzo J: Vascular calcification: Pathobiological mechanisms and clinical implications. Circ Res 2006;99:1044-1059.

110 Kiechl S, Werner P, Knoflach M, Furtner M, Willeit J, Schett G: The osteoprotegerin/rank/rankl system: A bone key to vascular disease. Expert Rev Cardiovasc Ther 2006;4:801-811.

111 Vattikuti R, Towler DA: Osteogenic regulation of vascular calcification: An early perspective. Am J Physiol Endocrinol Metab 2004;286:E686-696.

-112 Briese S, Wiesner S, Will JC, Lembcke A, Opgen-Rhein B, Nissel R, Wernecke KD, Andreae J, Haffner D, Querfeld U: Arterial and cardiac disease in young adults with childhood-onset end-stage renal disease-impact of calcium and vitamin d therapy. Nephrol Dial Transplant 2006;21:1906-1914.

113 Haffner D, Hocher B, Müller D, Simon K, Konig K, Richter CM, Eggert B, Schwarz J, Godes M, Nissel R, Querfeld U: Systemic cardiovascular disease in uremic rats induced by 1,25(oh)2d3. J Hypertens 2005;23:1067-1075.

114 Razzaque MS: The dualistic role of vitamin d in vascular calcifications. Kidney Int 2011;79:708-714.

115 Shroff R, Egerton M, Bridel M, Shah V, Donald AE, Cole TJ, Hiorns MP, Deanfield JE, Rees L: A bimodal association of vitamin d levels and vascular disease in children on dialysis. J Am Soc Nephrol 2008;19:1239-1246.

116 Zittermann A, Schleithoff SS, Koerfer R: Vitamin d and vascular calcification. Curr Opin Lipidol 2007;18:4146.

117 Zebger-Gong H, Muller D, Diercke M, Haffner D, Hocher B, Verberckmoes S, Schmidt S, D'Haese PC, Querfeld U: 1,25-dihydroxyvitamin d3-induced aortic calcifications in experimental uremia: Up-regulation of osteoblast markers, calcium-transporting proteins and osterix. J Hypertens 2011;29:339-348.

118 Zittermann A, Gummert JF, Borgermann J: The role of vitamin d in dyslipidemia and cardiovascular disease. Curr Pharm Des 2011;17:933-942.

119 Lopez I, Aguilera-Tejero E, Mendoza FJ, Almaden Y, Perez J, Martin D, Rodriguez M: Calcimimetic r-568 decreases extraosseous calcifications in uremic rats treated with calcitriol. J Am Soc Nephrol 2006;17:795804.

120 Lopez I, Mendoza FJ, Guerrero F, Almaden Y, Henley C, Aguilera-Tejero E, Rodriguez M: The calcimimetic amg 641 accelerates regression of extraosseous calcification in uremic rats. Am J Physiol Renal Physiol 2009;296:F1376-1385.

121 Koleganova N, Piecha G, Ritz E, Schmitt CP, Gross ML: A calcimimetic (r-568), but not calcitriol, prevents vascular remodeling in uremia. Kidney Int 2009;75:60-71.

122 Evolve Trial Investigators: Effect of cinacalcet on cardiovascular disease in patients undergoing dialysis. N Engl J Med 2012;367:2482-2494.

123 Luo G, Ducy P, McKee MD, Pinero GJ, Loyer E, Behringer RR, Karsenty G: Spontaneous calcification of arteries and cartilage in mice lacking matrix gla protein. Nature 1997;386:78-81.

124 Hessle L, Johnson KA, Anderson HC, Narisawa S, Sali A, Goding JW, Terkeltaub R, Millan JL: Tissuenonspecific alkaline phosphatase and plasma cell membrane glycoprotein-1 are central antagonistic regulators of bone mineralization. Proc Natl Acad Sci U S A 2002;99:9445-9449.

125 Collin-Osdoby P: Regulation of vascular calcification by osteoclast regulatory factors rankl and osteoprotegerin. Circ Res 2004;95:1046-1057.

126 Lorenz-Depiereux B, Schnabel D, Tiosano D, Hausler G, Strom TM: Loss-of-function enpp1 mutations cause both generalized arterial calcification of infancy and autosomal-recessive hypophosphatemic rickets. Am J Hum Genet 2010;86:267-272.

127 Munroe PB, Olgunturk RO, Fryns JP, Van Maldergem L, Ziereisen F, Yuksel B, Gardiner RM, Chung E: Mutations in the gene encoding the human matrix gla protein cause keutel syndrome. Nat Genet 1999;21:142-144.

128 Murshed M, McKee MD: Molecular determinants of extracellular matrix mineralization in bone and blood vessels. Curr Opin Nephrol Hypertens 2010;19:359-365.

129 Lomashvili KA, Cobbs S, Hennigar RA, Hardcastle KI, O'Neill WC: Phosphate-induced vascular calcification: Role of pyrophosphate and osteopontin. J Am Soc Nephrol 2004;15:1392-1401. 


\section{Kidney \\ Blood Pressure Research}

Kidney Blood Press Res 2013;37:68-83

DOI: $10.1159 / 000343402$

Publisnea onine: virarch 18, 2013

(C) 2013 S. Karger AG, Basel

www.karger.com/kbr

130 Lomashvili KA, Khawandi W, O'Neill WC: Reduced plasma pyrophosphate levels in hemodialysis patients. J Am Soc Nephrol 2005;16:2495-2500.

131 Lomashvili K, Garg P, O'Neill W C: Chemical and hormonal determinants of vascular calcification in vitro. Kidney Int 2006;69:1464-1470.

132 Lomashvili KA, Garg P, Narisawa S, Millan JL, O'Neill WC: Upregulation of alkaline phosphatase and pyrophosphate hydrolysis: Potential mechanism for uremic vascular calcification. Kidney Int 2008;73:1024-1030.

133 O'Neill WC, Sigrist MK, McIntyre CW: Plasma pyrophosphate and vascular calcification in chronic kidney disease. Nephrol Dial Transplant 2010; 25:187-191.

134 O'Neill WC, Lomashvili KA, Malluche HH, Faugere MC, Riser BL: Treatment with pyrophosphate inhibits uremic vascular calcification. Kidney Int 2011;79:512-517.

135 Riser BL, Barreto FC, Rezg R, Valaitis PW, Cook CS, White JA, Gass JH, Maizel J, Louvet L, Drueke TB, Holmes CJ, Massy ZA: Daily peritoneal administration of sodium pyrophosphate in a dialysis solution prevents the development of vascular calcification in a mouse model of uraemia. Nephrol Dial Transplant 2011;26:3349-3357.

136 Miyauchi A, Alvarez J, Greenfield EM, Teti A, Grano M, Colucci S, Zambonin-Zallone A, Ross FP, Teitelbaum SL, Cheresh D, et al.: Recognition of osteopontin and related peptides by an alpha v beta 3 integrin stimulates immediate cell signals in osteoclasts. J Biol Chem 1991;266:20369-20374.

137 Steitz SA, Speer MY, McKee MD, Liaw L, Almeida M, Yang H, Giachelli CM: Osteopontin inhibits mineral deposition and promotes regression of ectopic calcification. Am J Pathol 2002;161:2035-2046.

138 Wada T, McKee MD, Steitz S, Giachelli CM: Calcification of vascular smooth muscle cell cultures: Inhibition by osteopontin. Circ Res 1999;84:166-178.

139 Scatena M, Liaw L, Giachelli CM: Osteopontin: A multifunctional molecule regulating chronic inflammation and vascular disease. Arterioscler Thromb Vasc Biol 2007;27:2302-2309.

140 Dhore CR, Cleutjens JP, Lutgens E, Cleutjens KB, Geusens PP, Kitslaar PJ, Tordoir JH, Spronk HM, Vermeer C, Daemen MJ: Differential expression of bone matrix regulatory proteins in human atherosclerotic plaques. Arterioscler Thromb Vasc Biol 2001;21:1998-2003.

141 Min H, Morony S, Sarosi I, Dunstan CR, Capparelli C, Scully S, Van G, Kaufman S, Kostenuik PJ, Lacey DL, Boyle WJ, Simonet WS: Osteoprotegerin reverses osteoporosis by inhibiting endosteal osteoclasts and prevents vascular calcification by blocking a process resembling osteoclastogenesis. J Exp Med 2000;192:463-474.

142 Bucay N, Sarosi I, Dunstan CR, Morony S, Tarpley J, Capparelli C, Scully S, Tan HL, Xu W, Lacey DL, Boyle WJ, Simonet WS: Osteoprotegerin-deficient mice develop early onset osteoporosis and arterial calcification. Genes Dev 1998;12:1260-1268.

143 Baud'huin M, Lamoureux F, Duplomb L, Redini F, Heymann D: Rankl, rank, osteoprotegerin: Key partners of osteoimmunology and vascular diseases. Cell Mol Life Sci 2007;64:2334-2350.

144 Moe SM, Reslerova M, Ketteler M, O'Neill K, Duan D, Koczman J, Westenfeld R, Jahnen-Dechent W, Chen NX: Role of calcification inhibitors in the pathogenesis of vascular calcification in chronic kidney disease (ckd). Kidney Int 2005;67:2295-2304.

145 Nitta K, Akiba T, Uchida K, Kawashima A, Yumura W, Kabaya T, Nihei H: The progression of vascular calcification and serum osteoprotegerin levels in patients on long-term hemodialysis. Am J Kidney Dis 2003;42:303-309.

146 Price PA, Faus SA, Williamson MK: Warfarin-induced artery calcification is accelerated by growth and vitamin d. Arterioscler Thromb Vasc Biol 2000;20:317-327.

147 Cozzolino M, Brandenburg V: Warfarin: To use or not to use in chronic kidney disease patients? J Nephrol 2010;23:648-652.

148 Schurgers LJ, Teunissen KJ, Knapen MH, Geusens P, van der Heijde D, Kwaijtaal M, van Diest R, Ketteler M, Vermeer C: Characteristics and performance of an immunosorbent assay for human matrix gla-protein. Clin Chim Acta 2005;351:131-138.

149 Cranenburg EC, Brandenburg VM, Vermeer C, Stenger M, Mühlenbruch G, Mahnken AH, Gladziwa U, Ketteler M, Schurgers LJ: Uncarboxylated matrix gla protein (ucmgp) is associated with coronary artery calcification in haemodialysis patients. Thromb Haemost 2009;101:359-366.

150 Zebboudj AF, Shin V, Bostrom K: Matrix gla protein and bmp-2 regulate osteoinduction in calcifying vascular cells. J Cell Biochem 2003;90:756-765. 


\section{Kidney \\ Blood Pressure Research}

Kidney Blood Press Res 2013;37:68-83

DOI: $10.1159 / 000343402$

Publisned onIIne: TVarch 18, 2013

(C) 2013 S. Karger AG, Basel

www.karger.com/kbr

151 Price PA, Thomas GR, Pardini AW, Figueira WF, Caputo JM, Williamson MK: Discovery of a high molecular weight complex of calcium, phosphate, fetuin, and matrix gamma-carboxyglutamic acid protein in the serum of etidronate-treated rats. J Biol Chem 2002;277:3926-3934.

152 Schurgers LJ, Teunissen KJ, Knapen MH, Kwaijtaal M, van Diest R, Appels A, Reutelingsperger CP, Cleutjens JP, Vermeer C: Novel conformation-specific antibodies against matrix gamma-carboxyglutamic acid (gla) protein: Undercarboxylated matrix gla protein as marker for vascular calcification. Arterioscler Thromb Vasc Biol 2005;25:1629-1633.

153 Jono S, Ikari Y, Vermeer C, Dissel P, Hasegawa K, Shioi A, Taniwaki H, Kizu A, Nishizawa Y, Saito S: Matrix gla protein is associated with coronary artery calcification as assessed by electron-beam computed tomography. Thromb Haemost 2004;91:790-794.

154 Parker BD, Ix JH, Cranenburg EC, Vermeer C, Whooley MA, Schurgers LJ: Association of kidney function and uncarboxylated matrix gla protein: Data from the heart and soul study. Nephrol Dial Transplant 2009;24:2095-2101.

155 Galembeck F, Cann JR: Fetuin as a trypsin inhibitor. Arch Biochem Biophys 1974;164:326-331.

156 Hedrich J, Lottaz D, Meyer K, Yiallouros I, Jahnen-Dechent W, Stöcker W, Becker-Pauly C: Fetuin-a and cystatin c are endogenous inhibitors of human meprin metalloproteases. Biochemistry 2010;49:85998607.

157 Wang XQ, Hayes MT, Kempf M, Fraser JF, Liu PY, Cuttle L, Friend LR, Rothnagel JA, Saunders NA, Kimble RM: Fetuin-a: A major fetal serum protein that promotes "wound closure" and scarless healing. J Invest Dermatol 2008;128:753-757.

158 Lebreton JP, Joisel F, Raoult JP, Lannuzel B, Rogez JP, Humbert G: Serum concentration of human alpha 2 hs glycoprotein during the inflammatory process: Evidence that alpha 2 hs glycoprotein is a negative acutephase reactant. J Clin Invest 1979;64:1118-1129.

159 Denecke B, Graber S, Schafer C, Heiss A, Woltje M, Jahnen-Dechent W: Tissue distribution and activity testing suggest a similar but not identical function of fetuin-B and fetuin-A. Biochem J 2003;376:135-145.

$>160$ Jahnen-Dechent W, Schäfer C, Ketteler M, McKee MD: Mineral chaperones: A role for fetuin-a and osteopontin in the inhibition and regression of pathologic calcification. J Mol Med 2008;86:379-389.

161 Lee C, Bongcam-Rudloff E, Sollner C, Jahnen-Dechent W, Claesson-Welsh L: Type 3 cystatins; fetuins, kininogen and histidine-rich glycoprotein. Front Biosci 2009;14:2911-2922.

162 Heiss A, DuChesne A, Denecke B, Grotzinger J, Yamamoto K, Renne T, Jahnen-Dechent W: Structural basis of calcification inhibition by alpha 2-hs glycoprotein/fetuin-a. Formation of colloidal calciprotein particles. J Biol Chem 2003;278:13333-13341.

163 Heiss A, Jahnen-Dechent W, Endo H, Schwahn D: Structural dynamics of a colloidal protein-mineral complex bestowing on calcium phosphate a high solubility in biological fluids. Biointerphases 2007;2:1620.

164 Price PA, Toroian D, Lim JE: Mineralization by inhibitor exclusion: The calcification of collagen with fetuin. J Biol Chem 2009;284:17092-17101.

165 Toroian D, Lim JE, Price PA: The size exclusion characteristics of type i collagen: Implications for the role of noncollagenous bone constituents in mineralization. J Biol Chem 2007;282:22437-22447.

166 Toroian D, Price PA: The essential role of fetuin in the serum-induced calcification of collagen. Calcif Tissue Int 2008;82:116-126.

167 Ix JH, Wassel CL, Kanaya AM, Vittinghoff E, Johnson KC, Koster A, Cauley JA, Harris TB, Cummings SR, Shlipak MG, Study HA: Fetuin-a and incident diabetes mellitus in older persons. JAMA 2008;300:182-188.

168 Ix JH, Shlipak MG, Brandenburg VM, Ali S, Ketteler M, Whooley MA: Association between human fetuin-a and the metabolic syndrome: Data from the heart and soul study. Circulation 2006;113:1760-1767.

169 Weikert C, Stefan N, Schulze MB, Pischon T, Berger K, Joost HG, Häring HU, Boeing H, Fritsche A: Plasma fetuin-a levels and the risk of myocardial infarction and ischemic stroke. Circulation 2008;118:2555-2562.

170 Ketteler M, Bongartz P, Westenfeld R, Wildberger JE, Mahnken AH, Bohm R, Metzger T, Wanner C, JahnenDechent W, Floege J: Association of low fetuin-a (ahsg) concentrations in serum with cardiovascular mortality in patients on dialysis: A cross-sectional study. Lancet 2003;361:827-833.

171 Hermans MM, Brandenburg V, Ketteler M, Kooman JP, van der Sande FM, Boeschoten EW, Leunissen KM, Krediet RT, Dekker FW: Association of serum fetuin-a levels with mortality in dialysis patients. Kidney Int 2007;72:202-207. 


\section{Kidney \\ Blood Pressure Research}

Kidney Blood Press Res 2013;37:68-83

DOI: $10.1159 / 000343402$

Published online: IVarch 18, 2013

(C) 2013 S. Karger AG, Base

www.karger.com/kbr

172 Schaible J, Wigger M, Staude H, Drueckler E, Kundt G, Haffner D, Fischer DC: Serum fetuin-a and vitamin d in children with mild-to-severe chronic kidney disease: A cross-sectional study. Nephrol Dial Transplant 2012;27:1107-1113.

173 Shroff RC, Shah V, Hiorns MP, Schoppet M, Hofbauer LC, Hawa G, Schurgers LJ, Singhal A, Merryweather I, Brogan P, Shanahan CM, Deanfield J, Rees L: The circulating calcification inhibitors, fetuin-a and osteoprotegerin, but not matrix gla protein, are associated with vascular stiffness and calcification in children on dialysis. Nephrol Dial Transplant 2008;23:3263-3271.

174 Smith ER, Ford ML, Tomlinson LA, Rocks BF, Rajkumar C, Holt SG: Poor agreement between commercial elisas for plasma fetuin-a: An effect of protein glycosylation? Clin Chim Acta 2010;411:1367-1370.

175 Wigger M, Schaible J, Muscheites J, Kundt G, Haffner D, Fischer DC: Fetuin-a serum concentrations in healthy children. Ann Clin Biochem 2009;46:511-513.

176 Hamano T, Matsui I, Mikami S, Tomida K, Fujii N, Imai E, Rakugi H, Isaka Y: Fetuin-mineral complex reflects extraosseous calcification stress in ckd. J Am Soc Nephrol 2010;21:1998-2007.

177 Price PA, Lim JE: The inhibition of calcium phosphate precipitation by fetuin is accompanied by the formation of a fetuin-mineral complex. J Biol Chem 2003;278:22144-22152.

178 Price PA, Williamson MK, Nguyen TM, Than TN: Serum levels of the fetuin-mineral complex correlate with artery calcification in the rat. J Biol Chem 2004;279:1594-1600.

179 Matsui I, Hamano T, Mikami S, Fujii N, Takabatake Y, Nagasawa Y, Kawada N, Ito T, Rakugi H, Imai E, Isaka Y: Fully phosphorylated fetuin-a forms a mineral complex in the serum of rats with adenine-induced renal failure. Kidney Int 2009;75:915-928.

180 Smith ER, Ford ML, Tomlinson LA, Rajkumar C, McMahon LP, Holt SG: Phosphorylated fetuin-a-containing calciprotein particles are associated with aortic stiffness and a procalcific milieu in patients with predialysis ckd. Nephrol Dial Transplant 2012;27:1957-1966.

-181 Pasch A, Farese S, Graber S, Wald J, Richtering W, Floege J, Jahnen-Dechent W: Nanoparticle-based test measures overall propensity for calcification in serum. J Am Soc Nephrol 2012;23:1744-1752. 